\title{
TRANSFORMING THE NATION?
}

\section{THE BOLIVARIAN EDUCATION REFORM IN VENEZUELA}

\author{
Jared A. Abbott, Harvard University \\ Hillel David Soifer, Temple University (corresponding author) \\ Matthias vom Hau, Institut Barcelona d'Estudis Internacionals (IBEI)
}

\begin{abstract}
:
The Chávez government introduced a 'Bolivarian' national curriculum to promote radically different understandings of Venezuelan history and identity. We place the fate of this reform initiative within the broader study of state formation and nationalism. Scholars have long identified mass schooling as the key institution for socializing citizens and cultivating national loyalties, and many states have attempted to alter the nationalist content of schooling with these ends in mind. Venezuela constitutes an ideal case for identifying the specific conditions under which transformations of official national ideologies do and do not gain broader resonance. Using evidence derived from textbook analysis and semi-structured interviews with educational officials and teachers in Caracas, we highlight a new argument, showing that intrastate tensions between the central government and teachers, heightened by a well-established cultural machinery and by teachers' increasing exclusion from the Chavista political coalition, explain the limited success in government efforts to implement Bolivarian nationalism through the school curriculum.

Acknowledgements:

We received helpful comments on earlier versions from Javier Corrales, Fran Hagopian, Jorge Domínguez, Kai Thaler, and from audiences during presentations at the 2013 annual meeting of the Latin American Studies Association, the Harvard-MIT Latin America Discussion Group, Kassel University, and the desiguALdades.net Seminar Series at the Free University Berlin. Thanks also to Andy Rosati, whose assistance in Caracas during fieldwork was invaluable, and to Sergio Costa, Stefan Peters, and Manuela Boatcă. Research for this article was funded in part by Temple University.
\end{abstract}




\section{TRANSFORMING THE NATION?}

\section{THE BOLIVARIAN EDUCATION REFORM IN VENEZUELA}

Governments around the world have long assigned schooling a central role in creating national attachments and conveying official visions of national identity and history. ${ }^{1}$ Seen in this light, it is not surprising that the government of Hugo Chávez pursued an ambitious reform agenda in seeking to introduce Bolivarian nationalism into the educational sphere. ${ }^{2}$ This project culminated with the distribution of more than 100 million new textbooks which promote a radically different version of Venezuelan identity and history.

Yet despite the Herculean efforts of the central government, the extent of ideological change remained limited. Teachers, who are the first transmission belt of textbooks, resisted the new Bolivarian curriculum and questioned the content of the new texts. Interviews conducted across different school districts in Caracas show that only a small minority of teachers regularly use the new texts in their classrooms, and even this minority report that they frequently complement the official textbooks with nongovernment source materials. The reasons given by teachers center on objections to the reinterpretation of various aspects of Venezuelan history and politics; thus they are largely political rather than purely pedagogical.

\footnotetext{
${ }^{1}$ Eric J. Hobsbawm, Nations and Nationalism since 1780: Programme, Myth, Reality. (Cambridge: Cambridge University Press, 1990); Eugen Weber. Peasants into Frenchmen: The Modernization of Rural France, 1870-1914. (Stanford, CA: Stanford University Press, 1976).

${ }^{2}$ Bolivarianism is a complex, multi-layered, and often contradictory ideological project. In this article we focus only on one particular aspect of it: Bolivarian nationalism, or the understandings of national identity and history advanced by the Chávez government. On other important facets of Bolivarianism see for example Germán Carrera Damas, 'The Hidden Legacy of Simón Bolívar', in David Bushnell and Lester D. Langley (eds.), Simón Bolivar: Essays on the Life and Legacy of the Liberator (Lanham: Rowman \& Littlefield Publishers, 2008), chap. 9, on the cult of Simón Bolívar and Roger Burbach and Camila Piñeiro, 'Venezuela's Participatory Socialism' Socialism and Democracy 21.3 (2007), pp. 181-200 on the rise of Bolivarian socialism.
} 
How can we account for the contention over this effort at the transformation of nationalism under Chávez and for the extent of its implementation? This case constitutes an ideal case for evaluating recent theoretical advances in the scholarship on nationalism and ideological change more generally that identify the specific conditions under which new official nationalisms gain wider resonance. Three existing explanatory approaches link ideological change to socio-structural and political transformations. One argues that ideologies have fixed relations with the underlying social structure; that ideological change is primarily driven by socio-structural transformations, and that ordinary people are more likely to buy into an ideology if it reflects familiar social arrangements. ${ }^{3}$ One version of this 'correspondence' view, going back to Max Weber and Karl Marx, posits a direct link between economic and ideological transformation and holds that change results from the formation of new social groupings that seek political and symbolic representation. A second approach focuses on the rise of civil society, arguing that a dense associational life greatly facilitates the contestation of established ideologies and the consolidation of new ideological contents. ${ }^{4} \mathrm{~A}$ third literature is more politically focused, linking changes in official national ideologies to shifts in power configurations and ruling coalitions. ${ }^{5}$ In this view, changes in state-society alliances open up new spaces for the contestation of established national discourses, and entail a new strategic

\footnotetext{
${ }^{3}$ For a critical review of a correspondence-theoretical approach to ideological change see Robert Wuthnow, Communities of Discourse. Ideology and Social Structure in the Reformation, the Enlightment, and European Socialism (Cambridge, MA: Harvard University Press, 1989).

${ }^{4}$ Benedict Anderson,. Imagined Communities: Reflections on the Origins and Spread of Nationalism 2nd ed. (New York: Verso, 1983); Jürgen Habermas, The Structural Transformation of the Public Sphere: An Inquiry into a Category of Bourgeois Society. (Cambridge, MA: MIT Press, 1991).

${ }^{5}$ Philip S. Gorski, 'Nation-ization Struggles: A Bourdieusian Theory of Nationalism' In Philip S. Gorski (ed.), Bourdieusian Theory and Historical Analysis. (Durham, NC: Duke University Press, 2012); Michael Hechter, Containing Nationalism (Oxford: Oxford University Press, 2000); Andreas Wimmer, Nationalist Exclusion and Ethnic Conflict: Shadows of Modernity (Cambridge: Cambridge University Press, 2000).
} 
agreement on shared conceptions of nationhood to enable the articulation of collective interests.

These explanations cannot account for the Venezuelan experience. First, despite political turmoil, the last two decades in Venezuela have not seen the sort of economic and social changes said to engender transformations of nationalism. The rise of middle sectors and organized labor, and their incorporation into politics, happened during the mid- $20^{\text {th }}$ century, and no analogous shift in class structure has taken place since $1999 .{ }^{6}$ Second, while scholars have engaged in intense arguments over whether the rise of Chavismo as a political movement represents the independent flourishing of civil society or a dramatic shift in political alliances, neither view can account for the limited consolidation of Bolivarian nationalism. If Chavismo represents, as many commentators argue, an inclusionary alliance that incorporates subaltern sectors ${ }^{7}$, Bolivarian nationalism should be an increasingly hegemonic project, and we should see little contestation over these new understandings of nationhood. ${ }^{8}$ Yet we find serious contestation, meaning that ideological change cannot simply emanate from civil society. If instead we follow scholars who take the Chavista project to be an exclusionary and polarizing alliance ${ }^{9}$, we cannot understand the origins of the ideological change using a

\footnotetext{
${ }^{6}$ Ruth Berins Collier and David Collier, Shaping the Political Arena: Critical Junctures, the Labor Movement, and Regime Dynamics in Latin America (Princeton, NJ: Princeton University Press, 1991). ${ }^{7}$ George Ciccariello-Maher, We Created Chávez: A People's History of the Venezuelan Revolution (Durham, NC: Duke University Press, 2013); Gabriel Hetland, 'The Crooked Line: From Populist Mobilization to Participatory Democracy in Chávez-Era Venezuela', Qualitative Sociology 37: 4 (2014), pp. 373-401; David Smilde and Daniel Hellinger (eds.), Venezuela's Bolivarian Democracy: Participation, Politics, and Culture under Chávez (Durham, NC: Duke University Press, 2011).

${ }^{8}$ This is not to neglect the probably crucial role played by the Chavista alliance with the urban poor in motivating the state's decision to adopt Bolivarian nationalism initially. In this article, however, we are primarily concerned with the consolidation of this new official national ideology - the extent to which Bolivarian nationalism obtained hegemonic status - rather than why the state chose this particular form of nationalism.

${ }^{9}$ Allan R. Brewer-Carías, Dismantling Democracy in Venezuela: The Chávez Authoritarian Experiment (New York: Cambridge University Press, 2010); Javier Corrales and Michael Penfold-Becerra, Dragon in
} 
civil society framework. In either reading of Chavismo, then, this framework cannot fully account for the puzzle at hand.

In response to these shortcomings of existing explanations, this article develops a novel state-centered one, which begins by conceptualizing transformations of nationalism as a top-down endeavor initiated by the government to legitimate its broader political agenda, and then focuses on intrastate tensions, and on the ways in which state projects are resisted and subverted by elements of the state itself. Most state-centered scholarship on the limits to state projects focuses on state weakness as an obstacle to such transformations, and fails to disaggregate the state or explore tensions within it. ${ }^{10}$ The reality of the Venezuelan situation casts doubt on this approach. The state the Chávez government inherited was far from a weakling; it was a functioning state rather than a vacuum of power in which order and administration needed to be reconstructed.

Thus to explain the limited transformation of nationalism, we emphasize the critical role of state infrastructure, and the breadth of political coalitions - in particular whether state agents are included in the coalition promoting ideological change. We argue that the new official national ideology embraced by Chávez did not achieve hegemonic status: the government encountered a well-established cultural machinery, with set routines for the institutionalisation of ideological products and the socialisation of local state actors. In particular, the key disseminators, classroom teachers, were already trained under the previous ideological regime, and saw the new Bolivarian

the Tropics: Hugo Chávez and the Political Economy of Revolution in Venezuela (Washington, DC: Brookings Institution Press, 2011).

${ }^{10}$ On state weakness as an obstacle to transformative efforts, see Forrest D Colburn and Dessalegn Rahmato, 'Rethinking Socialism in the Third World' Third World Quarterly 13:1 (1992), pp.159-172 and Migdal, Joel Strong Societies and Weak States: state-society relations and state capabilities in the Third World (New York: Cambridge University Press, 1988). On the association between state weakness and limited nationalism in Latin America, see Centeno, Miguel Ángel Blood and Debt: War and the NationState in Latin America (University Park, PA: Penn State University Press, 2002) 
curriculum as a direct threat to their professional identity while feeling increasingly excluded from the coalition underpinning the reform. Moreover, these teachers had the collective organisation and mobilizing capacity to effectively resist the project of Bolivarian nationalism.

In developing this argument the article also fills a significant gap in the literature on Chavismo: we know fairly little about the ideological dimensions of the Bolivarian Revolution and its conception of nationalism. While it appears in the new name of the country and in many other elements of state discourse, the new Bolivarian vision of Venezuela remains understudied. We know little in systematic terms about how Bolivarian nationalism differs from older understandings of Venezuelan nationhood. And we know still less about how successful the Chavista government has been in implementing its new vision of national identity and history. This article seeks to address these shortcomings by exploring the Chavista educational reform as an attempt to inculcate a transformation of official nationalism.

The reminder of the article begins with a discussion of our conceptual and methodological approach. In the second section we compare the new Chavista textbooks and curriculum guidelines to pre-1999 texts, and non-government texts to analyze the contents of the new Bolivarian nationalism. In the third section we provide evidence on the extent to which this national ideology has been effectively implemented in Caracasarea schools, based largely on 55 interviews with teachers, school officials, NGO representatives, and education researchers. Finding some serious limits to its success, the fourth part of the article develops our explanatory argument focused on intrastate tensions. In the fifth section we show how teacher resistance to the new Bolivarian 
nationalism was shaped by the pre-existing state ideological infrastructure, and by the exclusion of these state agents from the governing coalition. We then conclude by highlighting the implications of our account and sketching an agenda for future research in this area.

\section{Transformations of Nationalism: Conceptual and Methodological Considerations}

This study draws on scholarship that conceives of nationalism as an ideology—a shared mental framework that supplies ways to imagine community, identify fundamental patterns of sameness and difference among people, make political claims, and organize social relations. ${ }^{11}$ Seen in this light, the basic underpinning of nationalism is the idea that that the world is divided into nations, each authentic entities with their peculiar history and culture; that political loyalty is primarily structured around nations; and that nations are or ought to be self-governed. ${ }^{12}$ In this article we specifically focus on official nationalism as an adaptable but explicit ideology advanced by states with the aim to legitimate their authority and achieve social control. ${ }^{13}$ Our main interest is in tracing and explaining the transformation of official national ideologies over time. As the case of Venezuela under Chávez illustrates, the contents of state-sponsored conceptions of national identity and history, of who is considered part of the national community, might change. Yet, even more importantly for the purposes of this article, the resonance of official nationalism is not a given. States might attempt to impose a new national

\footnotetext{
${ }^{11}$ Rogers Brubaker, Ethnicity without Groups (Cambridge, MA: Harvard University Press, 2004); Craig Calhoun, Nationalism (Minneapolis: University of Minnesota Press, 1997).

${ }^{12}$ Ernest Gellner, Nations and Nationalism (London: Oxford University Press, 1983); Anthony D. Smith, The Cultural Foundations of Nations: Hierarchy, Covenant, and Republic (Oxford: Blackwell Publishing, 2008).

${ }^{13}$ It bears emphasis that social movements and other civil society actors may employ counter-state nationalism in order to mobilize political support and challenge state authority. See Hechter Containing Nationalism.
} 
ideology, but the extent to which this official mode of identification gains acceptance among ordinary citizens and thus achieves hegemony might vary dramatically. ${ }^{14}$

Our conceptual approach has important methodological implications. Shared mental frameworks such as nationalism require social resources (e.g., financial means, administrative capacities, mass literacy, communication networks) in order to be created and maintained, and are therefore best studied not at the individual level, as subjective beliefs, but at the meso-level, as embedded in particular organizational settings. ${ }^{15}$ Thus we suggest that in order to gain hegemonic status, official national ideologies have to become regular products of state organizations.

In particular, our research strategy follows the classical works on nationalism and focuses on schooling as a key institution for the national socialization of citizens. School textbooks and teachers are especially critical in this regard. It is well-established that textbooks reveal the contents of state-sponsored national discourses, and that states employ considerable efforts and resources to shape them. Recent research also shows that teachers play a central role in the dissemination of textbook contents. ${ }^{16}$ Their worldviews and teaching practices shape how state-sponsored ideologies are received in the classroom. Teachers thus are crucial for the extent to which a new national ideology gains wider resonance.

Our analytical strategy follows from this methodological approach. We review the primary school textbooks for social science and history newly introduced by the Chávez

\footnotetext{
${ }^{14}$ Rogers Brubaker, Margit Feischmidt, Jon Fox, and Liana Grancea. Nationalist Politics and Everyday Ethnicity in a Transylvanian Town (Princeton, NJ: Princeton University Press, 2006).

${ }^{15}$ Wuthnow Communities of Discourse

${ }^{16}$ Gonzalo Portocarrero and Patricia Oliart. El Perú desde la escuela (Lima: Instituto de Apoyo Agrario, 1989); Matthias vom Hau, 'Unpacking the School: Textbooks, Teachers, and the Construction of Nationhood in Mexico, Argentina, and Peru', Latin American Research Review 44: 1 (2009): 127-54; Silvina Gvirtz, El discurso escolar a través de los cuadernos de clase, Argentina 1930-1970 (Buenos Aires: Editorial Universitaria de Buenos Aires, 1999).
} 
government and compare them to pre-1999 texts. ${ }^{17}$ This contrast allows us to trace changes in official nationalism. We also compare the new textbooks to non-government texts published after the onset of the Bolivarian Revolution to establish that the differences between pre- and post-1999 textbooks were not driven simply by timedependent factors like pedagogical fashions or global changes of nationalism.

To explore the understandings of national identity and history held by teachers and their textbook usage in the classroom we draw on 55 semi-structured interviews (conducted during the months of June-August 2012) with teachers, school officials, NGO representatives, and education researchers, while also drawing on the relevant secondary literature. Specifically, we conducted interviews with 26 primary school teachers in Caracas representing 18 different schools; 13 public, including three Bolivarian schools, and five private, in order to trace how the new Bolivarian textbook contents are received and negotiated in the classroom. ${ }^{18}$ To triangulate findings from teacher interviews we also consulted with six primary school principals and nine administrators from the municipal and national school systems. The interviews with the administrators, complemented by interviews with two representatives from the national Ministry of Education, including Maigualida Pinto, a Vice-minister for Education in 2012, also provided us with evidence on the actual unfolding of the Chavista reform initiative.

\footnotetext{
${ }^{17}$ Our methodological approach draws on vom Hau (2017) who uses textbooks to analyze nationalism in early and mid- $20^{\text {th }}$ century Latin America. Specifically, we trace similarities and differences in textbooks contents along the following four dimensions: (a) normative judgments of major historical epochs, such as recent history but also the colonial period; (b) the identity of the main actors driving national history; (c) representations of major national heroes and the reasons given to celebrate them; and (d) conceptions of main threats faced by the nation and ideas about hierarchies found within the national community. ${ }^{18}$ All school types are mandated to use the Colección Bicentenario and receive free copies of those texts (though not all schools, particularly private schools, actually received the texts in the year of our study), yet private schools usually have the highest degree of autonomy in the choice of the textbooks they use. Bolivarian schools, newly established under Chávez, stand at the other and of the spectrum, with little or no autonomy to choose their teaching materials, while ordinary national and municipal schools fall in between.
} 
Interviews with an editor from a major private publishing company specializing in textbooks and three representatives from leading NGOs working on education in Venezuela put the political struggles surrounding the reforms into sharp relief. Finally, we consulted with eight education specialists from prominent Venezuelan universities (Universdad Católica Andres Bello [UCAB], Universidad Simón Bolívar [USB], and Universidad Central de Venezuela [UCV]) to discuss our findings and argument in light of their own work and insights into the Chavista educational reforms.

As shown in the Appendix, we interviewed teachers from vastly different neighborhoods in the city, including Chacao, where the anti-Chavista opposition got 82 per cent of the vote, to Antímano, where Nicolás Maduro got over 70 per cent of the vote in the 2013 elections. These politically diverse neighborhoods can serve as a microcosm for the country as a whole, or at least for its urban areas, where one might expect educational efforts to be focused. We analyze textbooks and teacher interviews according to several major themes. In each of these sources we explore representations of central historical figures and events, as well as ideas about national inclusion and historical agency.

\section{Textbooks, Curriculum Guidelines, and the Contents of Ideological Change}

Official understandings of national identity and history have changed significantly since the Bolivarian era began in 1999, as reflected in the content of textbooks and school curricula. Most prominently, in 2007 the government introduced a new Bolivarian educational curriculum to replace the pre-Chavista one from 1997. The Bolivarian Curriculum explicitly dismisses its predecessor on the grounds that the latter's primary 
function is the creating a society based on the values of individualism, egoism, intolerance and consumerism. The Bolivarian Curriculum seeks to construct a new conception of national identity through the development of a "new citizen" for Venezuela, grounded in the principles of liberty, cooperation, social equality, unity, and Latin American integration and solidarity. ${ }^{19}$ While this curriculum was implemented in many schools, particularly Bolivarian schools, it was not officially established as the national educational curriculum, as this would require the passage of a new organic education law

A new organic education law was passed by the National Assembly in 2009. The law closely reflected the ideology of Bolivarian nationalism and sought to provide the 2007 Bolivarian Curriculum with a sufficient legal basis, but to date no special education law has been developed that would officially codify the 2007 curriculum as the national curriculum..$^{20}$ As we discuss below, opponents of the government's education reforms within the Venezuelan teacher corps cite the legal ambiguity of the 2007 curriculum as a justification for not following it in their classrooms. Two years later, in 2011, the government distributed 12 million copies of its new Colección Bicentenario free of charge to primary school students throughout Venezuela. For each grade 1-6, the Colección is a series of four books developed and produced by the Ministry of Education that follows the guidelines of the government's Bolivarian Curriculum, rather than the 1997 curriculum. After the death of Chávez in 2013 the government of Nicolás Maduro has remained committed to Bolivarian nationalism of its predecessor, as powerfully

\footnotetext{
${ }^{19}$ Ministerio del Poder Popular Para La Educación. Currículo Bolivariano Nacional: Diseño Curricular del Sistema Educativo Bolivariano (2007).

${ }^{20}$ James Suggett, 'Venezuelan Education Law: Socialist Indoctrination or Liberatory Education?'

Venezuelaanalysis.com, 21 August, 2009. Available at http://venezuelanalysis.com/analysis/4734
} 
indicated by the continued dissemination of the Colección. By 2015, more than 100

million copies of these texts had been distributed to Venezuelan students. ${ }^{21}$

$<$ TABLE 1 $>$

Textbook Representations of Key Historical Figures and Events

As shown in Table 1, the pre-1999 texts and the non-government texts published after 1999 stand in sharp contrast to the Colección Bicentenario embraced by Chavéz. The two most prominent differences - their representations of Simón Bolívar, and of Venezuelan history from 1958-1999 - are indicative of a shift from elitist to more popular understandings of national identity and history. They also illustrate the equation of the Chavista movement with the national community.

Given the centrality of Simón Bolívar in Venezuela's national mythology, ${ }^{22}$ it is not surprising that he figures prominently in all textbooks, regardless of publication date and political orientation. ${ }^{23}$ Yet the Colección represents Bolívar very differently. In the pre-1999 textbooks and the more recent non-government texts, Bolívar is portrayed primarily as an advocate of Latin American freedom from Spain, an opponent of federalism, and a liberal champion of separated powers. He is also treated as a symbol of

\footnotetext{
21 "100 milliones de libros de la Colección Bicentenario ha entregado la revolución." vtv.gob.ve, 26 September 2016, Available at http://vtv.gob.ve/100-millones-de-libros-de-la-coleccionbicentenario-ha-entregado-la-revolucion/

${ }^{22}$ Germán Carrera Damas, 'The Hidden Legacy of Simón Bolívar'; John Chasteen, 'Simón Bolívar: Man and Myth', in Samuel Brunk and Ben Fallow (eds.), Heroes \& Hero Cults in Latin America (Austin: University of Texas Press, 2006) pp. 21-39

${ }^{23}$ For a discussion of the centrality of Bolívar in non-government textbooks, see Carmen G. Arteaga Mora, 'Mito fundacional y heroes nacionales en libros de texto de primaria venezolanos' Revista Politeia 45: 1 (2010), pp. 50-53. For illustrations of Bolívar's importance in the Chavista understanding of history, see government's social science textbook for grade 5: América Bracho Arcila and María Helena León de Hurtado, Venezuela y Su Gente: Ciencias Sociales, Quinto Grado (Caracas: Ministerio del Poder Popular Para Educación, 2011), pp. 62-101, 125, 158.
} 
the unity and glory of the Venezuelan people. ${ }^{24}$ By contrast, in the Colección Bolívar's life and thought are framed as the philosophical and historical foundation of a range of Chavista political views. ${ }^{25}$ Bolívar is portrayed as an anti-imperialist whose preoccupation with Latin American integration is the foundation of current Latin American projects to distance the region from the influence of the United States and USbacked international institutions. For instance, Bolívar's pan-Latin American dream of turning Latin America into 'the biggest nation in the world' is equated in a single paragraph with the goal of contemporary leftist governments in Latin America 'to give a new impetus to Latin American integration with the aim of defending the region against globalization'26 Bolívar is also referred to as a socialist thinker who provides the intellectual framework for the 'socialist ethics' the government seeks to cultivate in Venezuelan society. ${ }^{27}$

Representations of Venezuelan history from 1958-1999 are also strikingly divergent. The pre-1999 texts and the non-government texts tend to view this period as the era of Venezuelan democracy, and to describe the Pact of Punto Fijo as a necessary measure in 'guaranteeing [Venezuela's]...nascent democracy' ${ }^{28}$ Little mention is made of the armed insurgency of the 1960s or of the exclusion of the Venezuelan Communist Party from the Pact. The 1989 Caracazo is mainly discussed as a series of popular

\footnotetext{
${ }^{24}$ Enlace con Ciencias Sociales Quinto Grado (Caracas: Editorial Santillana, 2010), pp. 174-176. See also Ciencias Sociales 5 (Caracas: S.A. Educación y Cultura Religiosa, 2001); Héctor Zamora, Estudios Sociales Quinto Grado (Caracas: Co-Bo, 2000); Arco Iris Basico: Ciencias Sociales 6 (Caracas: Librería Editorial Salesiana, 1988).

${ }^{25}$ Venezuela y Su Gente: Ciencias Sociales, Sexto Grado (Caracas: Ministerio del Poder Popular Para Educación, 2011), p. 63. See also Currículo Nacional Bolivariano: Diseño Curricular del Sistema Educativo Bolivariano (Caracas: MPPE, 2007).

${ }^{26}$ ibid.

${ }^{27}$ Hugo Chávez Frías, 'Tercer Motor: Moral y Luces, educación con valores socialistas' (Ministerio del Poder Popular para la Comunicación e Información, 2007), p. 20.

${ }^{28}$ Libro Integral: Mundo Tricolor 6 (Caracas: Fondo Editorial La Cadena Tricolor), p. 246; Mi Mundo 6 (1992), p. 52. Ciencias Sociales 6 (CO-BO, 2000), p. 153.
} 
protests or riots where the masses destroyed businesses, leading to over a thousand deaths and the massive destruction of private property ${ }^{29}$ Finally, little or no mention is made of the negative consequences of neoliberal economic policies undertaken by Venezuelan governments of the 1980s. Instead, the focus is on their intended effects. ${ }^{30}$

In sharp contrast, the Colección is highly critical of the Punto Fijo era, characterizing this as a period of "bipartidismo'31 that brought about the exclusion of ordinary Venezuelans from political participation and social welfare. It goes on to argue that the 'representative' democracy of this period had 'grave problems' from the beginning, leading eventually to the government's period of 'savage neoliberalism'32 in the 1980s which in turn gave rise to a 'popular rebellion...against inflation' known as the Caracazo. This narrative culminates in what it characterizes as the "new style of governance' of Hugo Chávez bringing about subordinate political and socioeconomic inclusion. $^{33}$

\section{Boundaries of National Inclusion and Historical Agency}

Textbook representations of race, ethnicity, gender and class also shed light on shifts in dominant understandings of nationhood. One difference related to race is how the texts depict African slavery in Venezuela. All the non-government textbooks and pre-1999 texts examined use the word 'esclavos' (slaves) to refer to enslaved peoples, ${ }^{34}$ whereas

\footnotetext{
${ }^{29}$ Mundo Tricolor 6, p. 251.

30 ibid., p. 249, 251. A more critical reading can be found in Civilización 5: Ciencias Sociales Educacion Basica (Caracas, Editorial Excelencia, 2000), p. 117-118.

${ }^{31}$ Venezuela y Su Gente, Sexto Grado, p. 100.

32 Ibid., p. 119.

${ }^{33}$ Ibid., pp. 121-123.

${ }^{34}$ Estudios Ciencias Sociales 4, p. 160; Arco Iris Basico: Estudios Sociales 5 (Caracas: Librería Editorial Salesiana, S.A., 1988), p. 40; Enlace Con Ciencias Sociales 5 (Caracas: Editorial Santillana, 2010), p. 154.
} 
the Colección Bicentenario instead uses 'esclavizados' (enslaved persons), ${ }^{35}$ presumably with the intention of avoiding the perception that people can be intrinsically suited to slavery. The Colección also places a greater emphasis on the resistance struggles of both African slaves ${ }^{36}$ and indigenous people ${ }^{37}$ against colonial rule, and depicts these struggles as crucial precursors to Venezuelan independence, illustrative of a greater emphasis on subordinate sectors as 'true' Venezuelans. ${ }^{38}$ The slave rebellion of José Leonardo Chirino (1795) and the failed multiracial uprising at La Guaira (1792) appear as key precursors of the independence movements of Miranda and Bolívar.

With its focus on indigenous and slave resistance, on the history of social movements during the Punto Fijo era, ${ }^{39}$ and on what it portrays as the necessary protagonist role played by subordinate sectors in Venezuelan democracy, ${ }^{40}$ it is clear that the Colección has a very different conception of historical agency from most other textbooks in Venezuela, which are much more elite-centered in their understanding of historical change. The Colección's representation of class also diverges from nongovernment texts in its conception of social cleavages, both domestic and global. The domestic social landscape is characterized as divided among the rich and the poor or between the opposition and pro-government actors, ${ }^{41}$ and the international social

\footnotetext{
${ }^{35}$ Venezuela y Su Gente, Cuarto Grado, p. 97,111; Venezuela y Su Gente, Quinto Grado, p. 80.

36 Venezuela y Su Gente, Quinto Grado, p. 98, 117-118.

${ }^{37}$ Ibid., pp. 81-82, 92.

${ }^{38}$ Universidad Católica Andrés Bello (UCAB), Escuela de Educación, Coordinación de Ciencias Sociales, 'Consideraciones sobre los libros de Ciencias Sociales de la Colección Bicentenario,' (Caracas: UCAB, 2011), p. 3.

39 Venezuela y Su Gente, Sexto Grado, p. 103, 106-112, 124.

${ }^{40}$ Ibid., p. 141.

${ }^{41}$ Venezuela y Su Gente, Sexto Grado, p. 91, 128, 131.
} 
landscape is characterized as a simple opposition between the Global North and the Global South, ${ }^{42}$ or between dependent and developed capitalist states. ${ }^{43}$

\section{Teachers and the Transmission of Ideological Change}

Having highlighted the dramatic changes in the content of official nationalism through a comparative analysis of school textbooks, we now turn to assessing the extent to which this ideological change has been effectively inculcated in Caracas-area schools. In so doing, we maintain our focus on schooling and draw on interviews with primary school teachers and education officials to trace the implementation of the new official national ideology.

Our findings suggest that the Chavista government has not been very successful in establishing the Colección Bicentenario as a means of disseminating its Bolivarian nationalism. Of the 26 classroom teachers interviewed, 15 reported using the Colección books at least to some extent, but only three reported using Colección texts as their class's primary texts. Furthermore, in most of the cases where teachers did report using the texts, they specified that they rarely used the social science series (the most politically-charged series of texts). Teachers who reported using the Colección in their classrooms reported using them as supplements to other, non-government source materials to ensure a balanced portrait of Venezuelan history.

These findings were corroborated in interviews with school administrators, education researchers, and representatives of education NGOs. In one municipality, for instance, the director of curriculum for the department of education reported that only a

${ }^{42}$ Venezuela y Su Gente, Cuarto Grado, p. 48.

${ }^{43}$ Venezuela y Su Gente, Sexto Grado, p. 46. 
small minority of teachers do use the texts (observing that this tended to track with the political leanings of each teacher). A researcher from the UCAB, who works closely with a number of nationally-run schools in the Antímano neighborhood of western Caracas, also reported wide variation in the usage of the government's texts among teachers in the area.

The government's limited success in implementing its ideological project is seen even more clearly in assessing teachers' use of the government's Bolivarian Curriculum. Only three teachers interviewed reported that the Bolivarian Curriculum was used in their schools, and one school principal who reported employing parts of it in his school mentioned that he was careful to ignore those aspects of the curriculum he found politically unpalatable: 'We only use the parts that we find useful', he said. ${ }^{44}$ Many of the teachers interviewed avoided using the curriculum altogether on the grounds that the preChávez curriculum from 1997 was still the official curriculum - since the 2009 education law mandated a special education law that had yet to be written. Even teachers who praised the Bolivarian Curriculum admitted that implementation was a problem in their schools. Finally, several teachers and administrators also commented that they would strongly resist any attempts by the national government to impose the Bolivarian curriculum in the future. The preceding findings thus suggest that a considerable gap exists between the rhetoric and reality of the government's education reforms. ${ }^{45}$ Manuel

\footnotetext{
${ }^{44}$ Interview with a (national) primary school principal in El Recreo parish, Caracas, August 2012.

${ }^{45}$ A few caveats, however, are in order. First, the Colección Bicentenario had only been in schools for one academic year at the time of these interviews. Further systematic research is certainly warranted on how teacher responses to the Colección evolved over time, yet informal conversations with teachers and administrators (during more recent stays in Venezuela for other research projects) indicate that their perceptions of those texts and their ways of using them in the classroom have not changed much since 2012. Second, several teachers and administrators interviewed reported that non-government textbooks have been increasingly influenced by Bolivarian nationalism, which suggests that focusing on the
} 
Anselmi, in a comparable study in Lara, arrives at a similar conclusion, writing that the limit of the Bolivarian nationalist project in shaping the minds of Venezuelan school children is directly 'a consequence of their teachers' tendency to ... resist the more openly political aspects of Bolivarianism'. ${ }^{46}$

Taken together, then, the evidence presented in this section has shown that even in strongly Chavista neighborhoods, resistance by teachers has stymied the implementation of the new official nationalism. And teacher reticence is crucial, since they are the actors charged with disseminating the Bolivarian nationalist project, not only through the textbooks they use, but through their actions in the classroom.

\section{Explaining Patterns of Ideological Change: The Analytical Framework}

Having shown that Bolivarian nationalism has (at least to date) not achieved wider resonance, the remainder of this article seeks to explain that finding. In this section we develop an explanatory framework. ${ }^{47}$ By contrast to scholarship that traces limited transformations of nationalism to socioeconomic conditions, the strength of civil society, political alliances, or state weakness, our account focuses on intrastate tensions; between the central authority and its radiating actors charged with implementing projects at the local level, such as school teachers. We highlight the irony that when rising political coalitions inherit a functional state cultural machinery upon taking power, it is the pre-

\footnotetext{
government's texts alone might understate the government's success in implementing its education agenda. These questions need to be addressed in further research.

${ }^{46}$ Anselmi, Manuel. Chavez's Children: Ideology, Education, and Society in Latin America (Lanham, MD: Lexington Books, 2013), p. 146.

${ }^{47}$ It bears emphasis that our analysis is solely focused on the attempt of the government to impose a new national ideology - Bolivarian nationalism - among ordinary citizens. Assessing the successes and failures of the wider political and ideological project associated with Chavismo is beyond the scope of this article.
} 
existing strength of the state, rather than its weakness, that limits the ability of state leaders to easily transform visions of nationhood. ${ }^{48}$

Explaining the implementation of ideological change thus requires close attention to the specific resources and relationships constitutive of state power. We see state power as being based on the logistical techniques and organizational resources at the disposal of the center, and a supportive relationship between the central and the local. ${ }^{49}$ The state's power, then, is infrastructural and relational. Of particular interest for our purposes is the relationship between the center of command and the local actors embedded in state 'radiating institutions.' Even if the state cultural machinery ${ }^{50}$ can rely on a strong financial basis and maintains a significant presence across national territory, the implementation of new ideological contents depends on the active collaboration of the actors situated within state institutions. Strained relationships undermine the ability to institutionalize newly adopted national ideologies. For our purposes, we focus on explaining when and why public school teachers may oppose the ideological outlook of the official curriculum and subvert its implementation.

To explain the existence of these tensions between the center and radiating actors we emphasize the presence of an already established ideological infrastructure, and the breadth of ruling coalitions. In a state infrastructure already established, ideological

\footnotetext{
${ }^{48}$ This analytical lens raises the important question of why states choose to transform the content of their national ideologies. We do not address this issue since our focus is firmly on the ability of states to implement these ideological projects when they emerge.

${ }^{49}$ Thus we approach the state as composed of differentiated networks of institutions and personnel that reach outwards from the center to control their realm. See Mann, Michael 'The Autonomous Power of the State: Its Origins, Mechanisms, and Results' European Journal of Sociology vol.25 \#2 (November 1984) pp.185-213; Soifer, Hillel David 'State Infrastructural Power: Approaches to Conceptualization and Measurement' Studies in Comparative International Development vol.43:3-4 (2008) pp.231-251.

${ }^{50}$ The state cultural machinery includes the organizational facilities directly dedicated to ideological production and dissemination.
} 
production is deeply routinized and professionalized. ${ }^{51}$ The inculcation of citizens and the promotion of particular ideological contents is embedded in organizational routines and often carried out by professional cadres that enjoy substantial autonomy from the center. In other words, where a new ruling coalition inherits an existing state apparatus, tensions between central state authorities and radiating actors are more likely to occur.

Several mechanisms underlie this regularity. One relates to professional socialization. When organizational routines are already well-established and local state actors have been trained under the previous ideological regime, this alone can generate motivation to oppose efforts to transform nationalism. Research in the sociology of professions shows that initial training and work experiences have long-lasting impacts on the worldviews and self-understandings held by members of a particular profession, whether teachers, archeologists, or radio broadcasters. ${ }^{52}$ Second, the rank and file of an established cultural machinery tends to have vested interests in the reproduction of the ideological status quo. Their inclination to resist ideological change is especially likely when they perceive a newly introduced national ideology as a threat to their professional status and future career paths. Third, an established ideological infrastructure also facilitates the collective organization of local state actors. The presence of vocational schools, training institutes and universities, professional bodies, workplace regulations, and typical career patterns usually contribute to a strong sense of professional identity

\footnotetext{
${ }^{51}$ For the domain of education, this routinization is indicated by a public school system that is able to administer and oversee a (nationally) binding curriculum and make schooling accessible to students across national territory.

52 Andrew Abbott, The System of Professions: An Essay on the Division of Expert Labor (Chicago, IL: University of Chicago Press, 2014); Paul DiMaggio, 'Constructing an Organizational Field as a Professional Project: U.S. Art Museums, 1920 -1940', in Walter W. Powell and Paul DiMaggio (eds.), The New Institutionalism in Organizational Analysis (Chicago, IL: University of Chicago Press, 1991), pp. $267-292$.
} 
and the formation of intra-professional networks, thereby enhancing the capacity of local state actors to resist the center.

The severity of these tensions also depends on the breadth of the new ruling coalition, and specifically on whether the rank and file of the state cultural machinery such as teachers are included within it. If coalitions include these actors and their collective organization, they are more likely to support the institutionalization of a new ideology. By contrast, if ruling coalitions are narrow and exclude radiating actors within the state, they are less likely to support the ideological change mandated by the center. Scholars of socialism have highlighted the role of sabotage by remnants of the old order as a key factor explaining the failure of post-revolutionary efforts to 'transition to socialism. ${ }^{53}$ These claims of 'foot-dragging' are common in accounts of the difficulty of ideological change more generally. Our argument offers a better-specified account of resistance to reform by identifying the individuals and groups most likely to participate in such activity and their reasons for doing so. But what is most novel about our argument is that it focuses not on the social remnants of the old order, but on its institutional remnants; its presence within the state.

\section{Intrastate Tensions and Limited Ideological Change in Venezuela}

If our argument is correct, then intrastate tensions constitute a crucial obstacle to the transformation of nationalism in Venezuela. We have already shown that teachers serve as the linchpin of efforts to consolidate an official national ideology, and that there is a lack of uptake among teachers in Caracas-area schools of the new vision of national identity promoted by the Chávez government. Teachers do not use the Colección

\footnotetext{
${ }^{53}$ Colburn and Rahmato 'Rethinking Socialism'.
} 
Bicentenario nearly as extensively as the government would prefer. In this section we turn to evidence for the explanatory account we have just developed; we will account for why teachers resist using these texts and implementing the new curriculum and trace their resistance to an already well-institutionalized state cultural machinery and to an increasingly exclusionary ruling coalition. We show that teachers were inculcated with previously dominant conceptions of nationalism, perceive the Chavista national project as a threat to their middle-class status and professional autonomy, are well-organized enough to make their opposition heard, and have been steadily isolated from the Chavista ruling coalition in the course of contention over educational reforms.

\section{Teachers' Political Justifications of Their Resistance}

In our interviews, we found two types of explanations — pedagogical and political—-for non-use of official texts. The pedagogical reasons given by teachers for not using the Colección Bicentenario were either that the texts were of inferior quality compared with other textbooks because the Colección would lack pictures and graphics, be too abstract, or did not supply enough follow-up activities for students.

Yet, the reasons given by teachers for not using the government's textbooks were not just pedagogical and practical. In fact, their motivation for resistance was usually highly political. The most adamant opponents of the texts reported that they either did not use them, or used them only minimally (especially the Social Science texts), because they objected to what they saw as the texts' dramatic reinterpretations of various aspects of Venezuelan history and politics. For instance, a national school teacher bluntly explained that she did not care for the government's new textbooks because 'my political 
perspective is totally different from that presented in the Colección', and because in her view 'the texts use the exact same language that the government uses!' ${ }^{2}$ Yet, even several teachers trained at the Universidad Bolivariana de Venezuela (UBV)—formed by the Chávez government with the intent to provide free higher education to formerly excluded sectors of the Venezuelan population - complained that in their view the texts were overly critical of the Punto Fijo era (1958-1998), which they argued was a period of genuine democracy in Venezuela, not an inferior form of representative democracy in need of replacement by a more profound form of participatory democracy (as suggested by the Colección). ${ }^{55}$ Other teachers argued that the new texts presented a one-sided picture of the colonial period that unfairly demonized Europeans: 'The books [the Colección] present the Conquistadors in a negative light...they came to loot, to rape, to take... and this has some truth, but we also have much to thank the Spanish for. They gave us a lot. Much of our culture comes from them. ${ }^{56}$

Teachers also gave a legalistic, but nevertheless politically motivated reason for not using the texts, arguing that since the contents of the books were not consistent with the national curriculum from 1997. Given the absence of a new one that would reflect the 2009 education law, the 1997 curriculum was still the legally binding one in their view, and they therefore had to rely on other texts to teach their students all the content mandated by it. Since teachers who used this argument were invariably critical of the Colección and the Bolivarian Curriculum who expressed deep frustration about the current direction of education reform in Venezuela and deep concern about what they saw as the increasing politicization of education in Venezuela, it is safe to say they saw

\footnotetext{
${ }^{54}$ Interview with teacher \#11, August 2012 (see appendix for list of teachers interviewed)

55 Interviews with teachers \#6, \#18, \#21, August 2012

56 Interview with teacher \#10, August 2012
} 
the 1997 curriculum as a bulwark against the imposition of Bolivarian nationalism upon education.

Finally, it is important to note that even among teachers who reported using the government's textbooks in the classroom, nine out of 15 were highly critical of the texts, and implied that the only reason they used them was because they were obligated to do so. For example, one teacher who used the texts at her public school job reported that she never used them at the private school where she also worked, since there she had more liberty to choose her own teaching material: 'The climate in private schools is more open than in public schools. Teachers have more liberty to develop their own materials...In private schools teachers can speak with more freedom than in public schools. ${ }^{57}$ Furthermore, several public school teachers who reported using the texts claimed that their students' families could not afford to purchase textbooks, and since the government's texts were better than nothing these teachers decided to use them. These findings suggest that even teachers who use the Colección Bicentenario are likely to resist teaching the more politically charged elements of the books. Thus while some resistance to the texts is not politically motivated, it is clear that to a large extent teacher non-use of the texts reflects conscious opposition to the government's education reform and its new conception of nationalism.

\section{Teachers, Pre-Existing State Strength, and Their Inclination to Resist}

Teachers' politicized views of the new texts and their opposition to the new Bolivarian Curriculum need to be analyzed within the context of state institutional development in Venezuela and the political alliance structures underpinning Chavismo. When the Chávez

\footnotetext{
${ }^{57}$ Interview with teacher \#5, August 2012
} 
government ascended to power, it encountered a state apparatus that was marked by inefficiency and limited in its distributive capacity due to the fluctuations of oil rents. Yet it was quite capable of performing basic state functions across national territory. ${ }^{58}$ More relevant for our purposes, in 1999 the Venezuelan state had a reasonably well-established cultural machinery, as indicated by a robust and well developed public education system that was able to provide throughout the country (though not without a certain degree of urban and class bias), and to systematize its provision across the country's schools. ${ }^{59}$

In crude numerical terms, this development can be seen in terms of the rate of school enrollment; on this indicator, the evidence shows that the Venezuelan state had significant capacity for decades before the rise of Chavismo. ${ }^{60}$ Average years of schooling doubled between 1960 and 1980, growing faster not only than the Latin American average but also faster than most countries in East Asia. Moreover, the wage premium for an additional year of schooling were significant, suggesting that educational

\footnotetext{
${ }^{58}$ Venezuela's performance on various indicators of state capacity placed it at or above average for South America. See Hillel David Soifer State Building in Latin America (New York: Cambridge University Press, 2015) pp.11-15. For a longer historical perspective on the infrastructural power of the Venezuelan state see Karl, Terry Lynn The Paradox of Plenty: Oil Booms and Petro-States (Berkeley, CA: University of California Press, 1991) and Coronil, Fernando The Magical State: Nature, Money, and Modernity in Venezuela (Chicago, IL: University of Chicago Press, 1997).

Crucially, our argument centers on the capacity of the state and not political institutions. The latter, of course, underwent a major crisis in the years prior to the initial election of Hugo Chávez, with the collapse of the country's major political parties. Even as Venezuela was gripped by a crisis of political institutions, and an economic crisis, many dimensions of its state remained effective. For two of many accounts of the political crisis of the 1990s that do not diagnose a crisis of state capacity, see Gustavo Flores-Macías After Neoliberalism? The Left and Economic Reforms in Latin America (New York: Oxford University Press, 2012), Chapter Four, and Margarita López Maya 'Venezuela: Hugo Chávez and the Populist Left' in Steven Levitsky and Kenneth M. Roberts, eds. The Resurgence of the Latin American Left (Baltimore, MD: Johns Hopkins University Press, 2011), Chapter Nine.

${ }^{59}$ According to data collected by Fernando Reimers, Venezuela's per capita education spending was by far the highest in Latin America in the 1970s and 1980s. Though austerity and adjustment measures did lead to some declines in public school provision and quality, and to increased urban and class bias in the educational system, these effects were quite muted in regional perspective. See Fernando Reimers 'The Impact of Economic Stabilization and Adjustment on Education in Latin America' Comparative Education Review vol.35 No.2 (May) pp.319-353.

${ }^{60} \mathrm{We}$ focus on secondary school enrollment because it varies more across time and country in contemporary Latin America than primary school enrollment.
} 
quality was robust in terms of its labor market returns. ${ }^{61}$ By the 1970 s, secondary school enrollment was already at 44 per cent, ranking the country fourth among 18 Latin American countries. ${ }^{62}$ Enrollment only increased substantially thereafter, reaching 56.4 per cent for the decade of the 1990s that immediately preceded the initial election of Hugo Chávez. Though Fernando Reimers shows that school provision and enrollment were higher in urban areas and for the non-poor, the extent of these biases was small in regional perspective. ${ }^{63}$

The centralization of the school curriculum under national oversight and regulation also reveals state institutional development. On this dimension, too, the Venezuelan education system demonstrated high capacity. The primary school system (which consists of grades 1-6) has two sectors, public and private, with around 83 per cent of Venezuelan primary school students attending public schools and around 17 per cent attending private schools. ${ }^{64}$ Within the public sector, there are three different, nominally independent systems, corresponding to the municipal, state and federal levels of government. This means that in municipalities or states that are governed by opposition governors or mayors, school administrators have at least some level of autonomy from national authorities. Yet the oversight capacity of the federal government is revealed by a closer inspection. Federally run schools (schools directly under the administration of the national Ministry of Education) comprise the vast majority (around

\footnotetext{
${ }^{61}$ Ortega, Daniel and Lant Pritchett (2014) 'Much Higher Schooling, Much Lower Wages: Human Capital and Economic Collapse in Venezuela' in Ricardo Hausman and Francisco Rodríguez, eds. Venezuela Before Chávez: Anatomy of an Economic Collapse (University Park, PA: Penn State University Press) Chapter Six.

${ }^{62}$ These figures are decade averages of data drawn from the World Development Indicators, available at http://data.worldbank.org/data-catalog/world-development-indicators

${ }^{63}$ Reimers 'The Impact of Economic Stabilization and Adjustment on Education in Latin America'

${ }^{64}$ Naracid Rodriguez and Mildred Mesa, "La Dirección Escolar en Venezuela", Revista Iberoamericana Sobre Calidad, Eficaz y Cambio en Educación 4.4 (2006): 1-22.
} 
70 per cent) of all public schools, with state-run schools consisting of around 26 per cent of public schools and the remaining few percent of public schools being run by municipalities. ${ }^{65}$ Moreover, the Ministry of Education sets the curriculum for all Venezuelan primary schools, and its administrative sub-units known as Zonas Educativas have oversight authority over all schools in a given area, both public and private. ${ }^{66}$ Consequently, despite their greater autonomy from the Ministry of Education than public schools, even private schools are subject to supervision and control by the Ministry of Education, as are municipal and state schools. ${ }^{67}$ Thus it is reasonable to think of the public education system as having the capacity to implement a nationally binding curriculum, and as having had this capacity before the Bolivarian project began in 1999 .

The development of public education can also be seen in the size and training of the teaching corps. As of 1970, Venezuela already had over 51,000 primary school teachers and 23,000 secondary school teachers, or about seven teachers for every one thousand residents. Again, though the number of teachers has grown sharply, especially in the last decade, and far faster than the rate of population growth, the sheer size of the teachers' corps in the Punto Fijo era shows that the state's power in this realm predates Chavismo.

Teachers were not only numerous, they were also trained and socialized by previously established state institutions. Though Venezuela's first normal school emerged only in 1936, by 1951, a sizable network of normal schools existed to train primary school teachers in a three or four year curriculum. Emphasis on training grew sharply

\footnotetext{
${ }^{65}$ Ibid. Since 2003 Venezuela has seen the emergence of two key educational initiatives: the missions and the Bolivarian schools. We address both in detail below.

${ }^{66}$ UNESCO, Datos Mundiales de Educación 7a edición: República Bolivariana de Venezuela (2010); Mariano Herrera, "El Sistema Educativa Venezolano," (Caracas: CICE, 2010).

${ }^{67}$ Rodriguez and Mesa 'La Dirección Escolar'
} 
after democratization in 1958, and by 1962 about 88 per cent of teachers in primary schools had titulos from normal schools. A 1969 reform shifted the emphasis of primary schooling from expansion to professionalization, and created a special track in secondary education for teacher training which led to the title of Bachiller Docente. This was complemented in 1980 with the creation of education tracks at major national universities, in which teachers received the title of Profesor $y$ Licenciado. ${ }^{68}$ The 1991 Reglamento del Ejercicio de la Profesión Docente established merit-based criteria for hiring. 69

Our interviews with teachers provide evidence that their professional socialization and status concerns played an important role in motivating opposition to the Bolivarian Curriculum and its new nationalist contents. Teachers, regardless of whether they teach at public or private schools, understand the representations of national history found in pre1999 textbooks as apolitical, non-ideological and thus 'true', in contrast to their perception of the Colección Bicentenario as politicized, ideological and ultimately 'false' depictions of Venezuelan history. In the words of a national schoolteacher. "it's like they [the texts] want to erase Venezuelans' memory and create a new history discovered by the politicians." ${ }^{\prime 70}$ And even some teachers that taught at the new Bolivarian schools, had complaints about what they saw as the new texts' inaccurate (and politically motivated) representations of historical figures such as Bolívar to make them conform to Chavista ideology. One of them, for instance, explained that in her view "they [the texts] want to

\footnotetext{
68 This discussion is based on Rodríguez Trujillo, Nacarid 'La Formación de Los Docentes de Venezuela de 1951 a 2001' in Luque, Guillermo, ed. Venezuela: Medio siglo de historia educativa 1951-2001 (Caracas: Ministerio de Poder Popular para la Educación Universitaria, 2011) pp.479-497.

${ }^{69}$ Ramírez, Tulio ‘Los Educadores: Una Agenda para la Valorización de Nuestros Educadores' in Ugalde, Luis, ed. Educación Para Transformar el País (Foro CERPE, Caracas, 2012) pp.111-129; Rodríguez Trujillo, Nacarid (2011) Historia de La Educación Venezolana: 6 Ensayos (Caracas: UCAB), pp.320-1. ${ }^{70}$ Interview with teacher \#8, August 2012
} 
associate Bolívar with socialism...but Bolívar never spoke of socialism, he spoke of the importance of democracy and he emphasized the importance of the right to private property."${ }^{.71}$ Another teacher pointed to representations of early $20^{\text {th }}$ century Venezuelan President Cipriano Castro to show how the Colección's perspective is politically motivated: "in his day he was a negative leader for the democratic process, but from today's point of view [that of the Colección] Cipriano Castro was a great revolutionary." ${ }^{.72}$ As these examples show, teachers generally do not further interrogate the ideological nature and political instrumentality of the textbooks published before 1999. In fact, pre-Chavista understandings of nationhood appear to enjoy largely hegemonic status among most of the teachers we interviewed.

In sum, then, various types of evidence point to the presence of a firmly consolidated education system at the onset of Chavismo. In 1999, the vast majority of school-age Venezuelan children were already taught under a well-institutionalized and nationally binding curriculum, while teaching involved significant professional socialization. These factors underpinned substantial opposition to the new Chavista nationalist project from these local state actors.

\section{Teacher Collective Organization and the Capacity to Resist}

Venezuelan teachers also had the organizational capacity to resist the consolidation of the new national ideology embraced by the Chávez government. Their history of formal collective organization predates Chavismo, dating back to the 1980 Ley Orgánica de

\footnotetext{
${ }^{71}$ Interview with teacher \#2, August 2012

${ }^{72}$ Interview with teacher \#16, August, 2012
} 
Educación that allowed teachers to unionize and participate in collective bargaining ${ }^{73}$ Teachers never formed a single encompassing union, retaining instead affiliations with both of the major parties of the Punto Fijo era. Yet this division did not reduce their level of unionization, which in fact increased due to the competition among unions affiliated with multiple parties, as thirteen unions competed for membership during the Carlos Andres Pérez government. Unable to coordinate negotiation with the state, and competing among themselves, Venezuela's teachers unions carried out more than thirty strikes between 1989 and $1993 .^{74}$

While the fragmented nature of unions in the educational sector prevented teachers from unifying to oppose or negotiate with the government ${ }^{75}$, it has not prevented teachers from mounting significant and often effective resistance to a range of government education policies. Since 1999 teacher unions repeatedly mobilized against government efforts to introduce a new national ideology into the educational sphere through curricular changes and a new education law. Most prominently, in 2001 many teachers vigorously opposed the radical Chavista- and government-supported National Education Project (PEN), and instead pushed for a more moderate compromise, the Organic Education Law Project (PLOE), which was a bipartisan effort to reform the education system that was backed both by prominent opposition groups such as the Asamblea de Educación as well as the Education Commission of the National

\footnotetext{
${ }^{73}$ Gindin, Julián 'Sindicalismo docente en América Latina: una contribución al debate’ El Cotidiano (JulyAugust 2011) pp.109-114, p.111. Rodríguez Trujillo Historia de La Educación Venezolana.p.274 discusses the 1969 primary school teachers' strike as a moment of professional identity formation among teachers. ${ }^{74}$ Murillo, M. Victoria 'From Populism to Neoliberalism: Labor Unions and Market Reforms in Latin America’ World Politics vol.52 (January 2000) pp.135-174. P.156 and Appendix.

75 Julián Gindin, "Sur, Neoliberalismo...¿Y Después? Los Sindicatos Docentes en Venezuela, Argentina, Bolivia, Brasil, Uruguay y Ecuador," Paper Presented at the Confederación de Educadores Americanos y STEI-Intersindical (Montevideo: 2009).
} 
Assembly. ${ }^{76}$ The organic law passed unanimously in the National Assembly, yet President Chávez refused to sign PLOE into law. At least some of the teachers' unions were also involved in anti-government mobilization in April 2002 and participated in strikes during $2003,{ }^{77}$ and continued to oppose subsequent attempts by Chávez, and later his successor Maduro, to pass a new education law and implement the new curriculum. The extent of teacher opposition supports our argument that resistance against the Bolivarian national project clearly emanated from within the state, and thus also supports our claim that the failure to date of nationalist transformation in Venezuela is not a consequence of state weakness.

\section{Teacher Exclusion from Reform Coalition}

Teacher resistance against the Bolivarian educational reform was further heightened by the steady narrowing of the coalition that underpinned this reform initiative. During the first years of the Chávez presidency there was initial support among the teaching corps for an educational reform. Yet after Chávez struck down the PLOE, teachers and their organizations approached subsequent stages of education reform with great suspicion. They viewed further attempts in 2004 and 2005 to reintroduce the education law into the National Assembly for a second vote as a blatant attempt by the government to push through the ideologically orthodox PEN as the legal basis for a radical Chavista reform project.

\footnotetext{
${ }^{76}$ Luis Bravo Jáuregui, "Legislación educativa en Venezuela. Iniciativas y controversia pública en torno a los ajustes normativo-políticos que demanda la Constitución de 1999," (Caracas: Memoria Educativa Venezolana, Universidad Central de Venezuela, 2009), 8.

${ }^{77}$ Much of the discussion in this section is based on Ramírez, Tulio 'Los Educadores' especially pp.113116.
} 
In light of wide-spread protest by teachers (in alliance with other civil society and opposition actors) Chávez changed his approach. In 2007 the government introduced a new Bolivarian Curriculum that had been developed in the Ministry of Education without much consultation with teachers. The government sought to establish a legal basis for this new curriculum through a sweeping constitutional reform package that included an amendment (to article 103 of the constitution) that would have mandated education to be based on the "humanistic principles of Bolivarian socialism." The constitutional referendum provoked massive protests by teacher unions and related education NGOs and ultimately failed. In response the Chávez government returned to seeking legislative approval for its educational reform project. This culminated in the passage of a new education law in 2009, which was strongly critiqued by a range of teachers' unions, ${ }^{78}$ some of whom openly suggested that they would use civil disobedience tactics to resist the law, and that since a new special law for basic education was not yet written, the 1997 curriculum in fact remained in effect. ${ }^{79}$

Thus, despite the structural limitations imposed by the fragmented nature of collective organization in the education sector, teachers have played an important role in resisting Chavista education reforms. This makes teacher opposition to the implementation of the Colección Bicentenario consistent with a long-standing pattern of teacher resistance that is, as we have shown, closely related to an already wellinstitutionalized educational apparatus and the increasingly exclusionary nature of the education reform process.

\footnotetext{
${ }^{78}$ Gindin 'Sindicalismo docente en América Latina', 36.

79 James Suggett, "Venezuelan Education Law: Socialist Indoctrination or Liberatory Education?"

Venezuelaanalysis.com (August 21, 2009).
} 


\section{Government Responses to Intrastate Resistance and Their Limitations}

Chávez, and more recently Maduro, have pursued a variety of measures to overcome intrastate opposition by teachers and their organizations and still be able to implement its new Bolivarian national ideology. The most direct initiatives were a series of challenges to the professional autonomy of educators. Decree \#1011 of 2001 created a system of education supervisors with the power to suspend teachers and keep them out of the classroom while administrative appeals unfolded. ${ }^{80}$ Chávista governments have also pursued a variety of more gradual strategies to break resistance among the teaching corps. Most prominently, the Education Ministry moved away from purely merit-based criteria and introduced political priorities into the hiring of new teachers. ${ }^{81}$ Another strategy has been a shift to greater reliance on interinos as opposed to titulares in the education corps, with the attendant reduction in job security. ${ }^{82}$ Finally, the Chávez government sought to establish a parallel teacher union, the SINAFUM, and gave it official recognition for collective bargaining.

Two additional lines of response merit more extended discussion. One strategy has involved attempts to create new institutions to circumvent resistance from within the established state educational infrastructure through the creation of education 'missions,' and the introduction of a 'Bolivarian' school system. Another line of response has

\footnotetext{
${ }^{80}$ Education reforms trigger Chavez protest Oxford Analytica Daily Brief Service. (Apr 16, 2001)

${ }^{81}$ A preference was given for graduates of the Misión Sucre rather than the graduates of the Universidad Pedagógica Experimental Libertador who have undergone formal pedagogical training.

${ }^{82}$ Interinos are teachers hired on a temporary basis, while titulares have a permanent contract (Bruni Celli, Josefina, Olgo Ramos and Milko González "Los Maetros en Venezuela: Carreras e Incentivos (Banco Interamericano de Desarrollo: Red de Centros de Investigación, 2001), 9, 17
} 
focused on teacher monitoring, training workshops, and limits on private-sector textbook production as more direct attempts to overcome these intra-state tensions. ${ }^{83}$

\section{Circumventing Tensions Through Parallel Institutions}

In 2003 the government established three education 'missions' to provide educational services to Venezuelans who have been excluded from traditional public and private education. ${ }^{84}$ The missions are funded by direct transfers from the state oil company, PDVSA, which frees them from congressional oversight and effectively creates a parallel education system in the country. ${ }^{85}$ Each mission tackles a different area of education, with mission Robinson providing literacy and grade-school equivalency degrees, mission Ribas providing high-school equivalency degrees, and mission Sucre providing - through a network of 'Bolivarian Universities' - a college education. While the missions have dramatically expanded educational enrollment (especially at the higher-education level), they have been widely criticized for succumbing to patronage and cronyism (many participants in each of the missions receive monthly scholarships), establishing substandard education, and for taking funds away traditional educational institutions. ${ }^{86}$ Yet what makes the missions particularly appealing to the Chávez and Maduro

\footnotetext{
${ }^{83}$ In other contexts where ideological change has been attempted, government-owned media have been used to disseminate the new official nationalism. Though critics of the Chávez government often point to community media as another mouthpiece of the state, scholars of Venezuelan community radio and television show that they should not be seen as part of the state ideological apparatus. See Fernandes, Sujatha Who Can Stop the Drums? Urban Social Movements in Chávez's Venezuela (Durham, NC: Duke University Press, 2010); Schiller, Naomi 'Catia Sees You: Community Television, Clientelism, and the State in the Chávez Era' in Smilde, David and Daniel Hellinger, eds. Venezuela's Bolivarian Democracy: Participation, Politics, and Culture under Chávez (Durham, NC: Duke University Press, 2011) pp.104-130. ${ }^{84}$ Kirk A. Hawkins, Guillermo Rosas, and Michael E. Johnson 'The Misiones of the Chávez Government' in Smilde, David and Daniel Hellinger, eds. pp.192.

85 ibid., 190.

${ }^{86}$ Ibid.; Steve Ellner, Rethinking Venezuelan Politics: Class, Conflict and the Chávez Phenomenon (Boulder, CO and London: Lynne Rienner Publishers, 2008), p.133.
} 
governments is that they allow it to employ a Bolivarian curriculum without resistance from its instructional corps.

Another parallel education initiative, the Bolivarian school system, introduced very early in the Chávez presidency, has grown with the availability of money from oil revenues. ${ }^{87}$ This program expanded rapidly from an initial 559 schools in 1999 to over 9,000 schools in 2012. ${ }^{88}$ Like the missions, the purpose of the Bolivarian schools is to incorporate marginalized Venezuelans into the educational system, in this case by increasing the length of the school day to provide additional cultural and sporting activities for students, and by providing students with daily meals and with preventative health services. Like the missions, Bolivarian schools are widely considered to push Bolivarian ideological beliefs on faculty and students. ${ }^{89}$

Both the missions and the Bolivarian schools represent an attempt to circumvent intrastate resistance to ideological transformation through the construction of new vehicles for its inculcation. Yet, their actual impact as parallel institutions should not be overstated. First, none of the missions serve primary school age students and thus they are not a likely venue for inculcating young students with a new conception of nationalism. While around 40 percent of all Venezuelan primary school students go to schools associated with the Bolivarian system, ${ }^{90}$ this figure is surpassed by the number of primary students attending private or non-national public schools (i.e. state or municipal schools) where the ideological pressure on teachers to conform to Bolivarian ideology is

\footnotetext{
${ }^{87}$ Anselmi Chavez's Children, p. 58

${ }^{88}$ Ministerio del Poder Popular Para la Educación, Memoria y Cuenta 2013, 1575.

${ }^{89}$ Although several teachers interviewed for this study reported no experience of ideological pressuring from colleagues or administrators in Bolivarian schools, in several cases teachers in these schools reported experiencing a culture of ideological dogmatism and expressed fear of losing their jobs if their oppositional political views became known.

${ }_{90}$ Ministerio del Poder Popular Para la Educación, Memoria y Cuenta 2013, 1575.
} 
likely not as strong. ${ }^{91}$ This suggests that even if the government has more success disseminating its conception of nationalism in Bolivarian schools, there are limits to the extent to which this mechanism can be employed. Furthermore, several of the teachers in Bolivarian schools interviewed for this study reported no experience of ideological pressuring either of themselves or of colleagues, so it is not clear that these schools are necessarily more effective in assuring compliance with the government's ideological agenda than other schools.

\section{Overcoming Resistance Through Micro-Management}

The education bureaucracy has also sought to overcome teacher resistance through teacher monitoring, workshops to train teachers in the use of the Colección Bicentenario, and limits on private-sector textbook production. Here again our preliminary evidence suggests that the government has struggled in implementing these measures. With respect to teacher monitoring, only six teachers interviewed reported having been visited by a government supervisor, and only eight out of 26 reported feeling any pressure to adopt the Bolivarian Curriculum or to use the Colección as their classes' primary text-books. Several teachers did report feeling substantial pressure to conform to the government's education agenda, complaining that they felt limited in what they could teach by political constraints, and a number of teachers reported seeing Chávez campaign posters hanging in their schools, and several expressed concern about even speaking with us out of fear of political reprisal.

\footnotetext{
${ }^{91}$ Instituto Nacional de Estadística, "Matrícula de educación primaria por dependencia", available at www.ine.gov.ve/index.php?option=com_content\&view=category\&id=64\&itemid=39\#
} 
Overall, however, the extent of real and perceived teacher monitoring appeared to be relatively low. School administrators and education experts we interviewed coincided with Maigualida Pinto, a Vice-Minister of Education, in accounting for this relatively low-level of government supervision by explaining that the government has only a small corps of school inspectors at its disposal, that the ideological commitment of many inspectors to the government is questionable, and that resistance to the government's reforms among school administrators and teachers limits the extent of self-monitoring that occurs. These last two factors, in particular, resonate quite clearly with our argument. $^{92}$

Nor have teacher training workshops been broadly implemented. Though school officials reported that many workshops had already taken place and that many more were being planned, none of the teachers we interviewed reported having attended a government-run workshop on the Colección Bicentenario. In fact several reported receiving no instruction whatsoever in the use of the textbooks. Thus the ultimate success of teacher-training workshops in increasing usage of the government's textbooks is unclear.

Finally, there is evidence that the government has had some success crowding out private textbook producers. Not only did many teachers report being told that they were no longer allowed to request that students buy any textbooks, but the Ministry of Education issued a circular in October 2011 that expressly forbade the use of any textbooks other than the Colección Bicentenario in public schools. ${ }^{93}$ These actions led to

\footnotetext{
${ }^{92}$ Anselmi Chavez's Children p.120ff finds weekly meetings of school coordinators at a regional level, and weekly rounds of school inspections by district officials. There, in other words, the "ideological management" of education is intense.

${ }^{93}$ La Zona Educativa de Miranda, Circular No. MDZ-2011-06, October 13, 2011.
} 
a decrease in one publishing house's primary school textbooks sales of over 25 per cent in 2011, and an anticipated drop of 60 per cent in 2012. However, while these figures suggest that lack of access to alternative texts could force teachers to rely more heavily on the government's textbooks in the future, the ineffective enforcement mechanisms coupled with the continued availability of alternative texts seems thus far to have limited the government's attempts to micro-manage textbook use at schools.

\section{Conclusion}

In this article we have explored nationalism and ideological change in Venezuela through the analytical lens of schooling. Since taking power, the Chávez government sought to transform dominant understandings of nationhood, placing educational reform at the center of this ideological project. The development and implementation of a new Bolivarian school curriculum have the intention, and the potential, to transform Venezuelan national identity in fundamental ways. Indeed, the conceptions of nationhood mandated for Venezuelan schools have undergone significant changes since Chávez was elected in 1999. Yet, the transmission of the new Bolivarian nationalism has been constrained. We argue that this is because teachers, as key disseminators of statesponsored ideological content, have opposed the new ideological contents.

To account for this limited transformation of nationalism we have developed an explanatory argument focused on intrastate tensions. We argued that these tensions are shaped by the presence of an already well established state ideological infrastructure and by whether local state agents and their collective interest representations have a place in the governing coalition. More concretely, we argue that tensions between the Chávez and 
Maduro governments and teachers undermined the implementation of the new Bolivarian curriculum. A well-established education system prior to Chávez's election led to a wellorganized teaching corps that was socialized under the previous ideological regime and that has had the motivation and capacity to resist the Chavista ideological project, while an increasingly exclusionary reform coalition further enhanced teacher resistance against the Bolivarian educational reform and its nationalist contents.

This analytical focus allows us to deepen our understanding of the Venezuelan state and address lacunae in the existing literature. Here, one strand of scholarship reifies the Venezuelan state as standing astride society, but detached and disengaged from it because of its access to resource rents. ${ }^{94}$ A second, more recent, literature, directly critical of this first strand and largely focused on the Chavista period, de-centers the state, exploring instead the agency of societal actors, and in particular subaltern ones formerly excluded during the Punto Fijo era, in shaping contemporary Venezuelan political discourse. ${ }^{95}$ While the first approach overstates the unitary and monolithic nature of the state, and its capacity to exert its will, the second moves too quickly to discard state initiatives and state agency in exploring contemporary ideological change.

By contrast, our article moves beyond both of these views to develop a nuanced and complex picture of the state while continuing to see it as a central (and indeed the central) force in the political arena. The educational reform and its aim to create new Bolivarian citizens is clearly a top-down initiative, yet it is crucially mediated and reworked by actors situated with the state cultural machinery, most prominently teachers.

\footnotetext{
${ }^{94}$ Karl Paradox of Plenty; Coronil The Magical State.

95 Smilde, David \& Daniel Hellinger, eds. Venezuela's Bolivarian Democracy; Ciccariello-Maher, George We Created Chávez: A People's History of the Venezuelan Revolution (Durham, NC: Duke University Press, 2013).
} 
Thus our findings caution against the portrayal of the state under Chávez as an allpowerful leviathan, while simultaneously maintaining the analytical focus on the national state, rather than following recent trends of privileging the study of local, communitybased ideological infrastructure. ${ }^{96}$

Our argument also sheds new light on debates around the missions introduced under Chávez. Much of the existing literature on the subject treats missions as political vehicles, primarily created to generate support for the Chavista government via clientelist ties and cronyism. ${ }^{97} \mathrm{We}$ find that other motives may underlie their creation: at least in the context of education, one motive for the introduction of the missions was to circumvent the already established public schooling system. Missions serve as parallel state infrastructure, and not just as machines for generating political support.

The findings of this article also place contemporary Venezuela within a broader comparative context. The limited transformation of nationalism under Chávez is not unique. More than 60 years ago, the rise of Peronism marked a dramatic social and political rupture in Argentina, with major implications for nationalism. ${ }^{98}$ After his 1946 election, Perón sought to redefine official conceptions of Argentine identity and history in light of the popular and at the same time highly personalistic movement he was leading. Educational reform constituted the central backbone of this ideological project too. ${ }^{99}$ The storyline is surprisingly familiar: Perón confronted substantial and wellorganized resistance from within the state. In an already established educational system,

\footnotetext{
96 Smilde and Hellinger, eds. Venezuela's Bolivarian Democracy (2011)

${ }^{97}$ Hawkins, Kirk Venezuela's Chavismo and Populism in Comparative Perspective (New York: Cambridge University Press, 2010), Chapter Seven.

98 Torre, Juan Carlos.La vieja guardia sindical y Perón. (Buenos Aires: Sudamericana, 1990).

99 Plotkin, Mariano. Mañana es San Perón: a Cultural History of Peron's Argentina (Wilmington, DE:

Scholarly Resources, 2002)
} 
teachers were socialized under the previous ideological regime, and their professional status placed them squarely within the middle-class, and outside the Peronist ruling coalition. ${ }^{100}$ Similarly limited transformations of nationalism can also be found in Peru under the military government of Juan Velasco Alvarado (1968-1975), and, beyond Latin America, in Turkey under the rule of the DP (Democrat Party) during the 1950s. ${ }^{101}$ In all these cases, a focus on state infrastructural development and intrastate tensions offers a plausible account of limited ideological change. The explanatory power of this analytical framework is further reinforced by cases in which a hegemonic transformation of nationalism succeeded, most prominently postrevolutionary Mexico under Cárdenas or the "Estado Novo" under Getulio Vargas in Brazil, where the strength of the existing state cultural machinery was different. ${ }^{102}$

More generally, Venezuela firmly shows that it is difficult to establish a direct link between socioeconomic change on one hand, and the extent or limits of the transformation of nationalism on the other. The Venezuelan case also demonstrates the shortcomings of explanations that center on state weakness to account for limited ideological change. The analysis presented in this article, by contrast, encourages future research to remain attuned to state infrastructure and intrastate relations to account for whether transformations of official nationalism become hegemonic or remain limited — in Venezuela and beyond.

\footnotetext{
${ }^{100}$ vom Hau 'State Infrastructural Power and Nationalism'; vom Hau 'Unpacking the school'

${ }^{101}$ Karpat, Kemal H. Social Change and Politics in Turkey: A Structural-Historical Analysis (Leiden: Brill 1973).

102 vom Hau 'State Infrastructural Power and Nationalism'
} 
Appendix

\section{Textbooks Consulted}

\section{Non-Government Texts:}

Arco Iris Basico: Estudios Sociales 5 (Caracas: Librería Editorial Salesiana, S.A., 1988).

Arco Iris Basico: Estudios Sociales 6 (Caracas: Librería Editorial Salesiana, S.A., 1988).

Arco Iris Básico: Ciencias Sociales 6 (Editorial Salesiana, 2000).

Marlene Arteaga Quintero, Arco Iris Venezolano 6: Libro Integral Para Sexto Grado de

Educación Básica (Caracas: Fundación Editorial Salesiana, 2005).

Ciencias Sociales 5 (Caracas, S.A. Educación y Cultura Religiosa, 2001).

Ciencias Sociales 5 (CO-BO, 2000).

Ciencias Sociales 6 (CO-BO, 2000).

Enlace con Ciencias Sociales Quinto Grado (Caracas, Editorial Santillana, 2010).

Enlace con Ciencias Sociales Sexto Grado (Caracas, Editorial Santillana, 2010).

Héctor Zamora, Estudios Sociales Cuarto Grado (Caracas: Co-Bo, 2000).

Héctor Zamora, Estudios Sociales Quinto Grado (Caracas: Co-Bo, 2000).

Héctor Zamora, Estudios Sociales Sexto Grado (Caracas: Co-Bo, 2000).

Mi Mundo 6 (1992)

Libro Integral: Mundo Tricolor 4 (Fondo Editorial La Cadena Tricolor, 2005).

Libro Integral: Mundo Tricolor 5 (Fondo Editorial La Cadena Tricolor, 2005).

Libro Integral: Mundo Tricolor 6 (Fondo Editorial La Cadena Tricolor, 2005).

Libro Integral: Saber Cuarto Grado (Editorial Cadena Capriles, 2010).

Libro Integral: Saber Quinto Grado (Editorial Cadena Capriles, 2010).

Libro Integral: Saber Sexto Grado (Editorial Cadena Capriles, 2010). 
Omar Galíndez, Civilización 5: Ciencias Sociales Educación Básica (Caracas: Editorial Excelencia C.A., 2000).

Vicente Barberá, Estudios Sociales 5 (Caracas: Librería Editorial Salesiana, 1988).

\section{Colección Bicentenario:}

América Bracho Arcila and María Helena León de Hurtado, Venezuela y Su Gente:

Ciencias Sociales, Cuarto Grado (Caracas: Ministerio del Poder Popular Para Educación, 2011).

, Venezuela y Su Gente: Ciencias Sociales, Quinto Grado (Caracas: Ministerio del Poder Popular Para Educación, 2011).

, Venezuela y Su Gente: Ciencias Sociales, Sexto Grado (Caracas: Ministerio del Poder Popular Para Educación, 2011).

\section{Curricula/Government Documents Consulted}

Currículo Básico Nacional: Nivel de Educación Básica. (Caracas: ME, 1997).

Currículo Nacional Bolivariano: Diseño Curricular del Sistema Educativo Bolivariano

(Caracas: MPPE, 2007).

El Congreso de la República de Venezuela, Ley Orgánica de Educación (Caracas: 1980).

Hugo Chávez Frías, Decreto \#303, Reglamento General de la Ley Orgánica de

Educación, Gaceta Oficial \#36.787 de Fecha 15 de septiembre de 1999 (Caracas:

República Bolivariana de Venezuela, 1999). 
Hugo Chávez Frías, Tercer motor: Moral y Luces, educación con valores socialistas :

juramentación del Consejo Presidencial Moral y Luces, Sala Ríos Reyna - Teatro Teresa

Carreño (Caracas: República Bolivariana de Venezuela, 2007).

La Asamblea Nacional de la República Bolivariana de Venezuela, Ley Organica de

Educación (Caracas: 2009).

\section{Teachers Interviewed}

\begin{tabular}{|c|l|l|l|l|l|l|}
\hline$\#$ & $\begin{array}{c}\text { School } \\
\text { Type }\end{array}$ & \multicolumn{1}{|c|}{ Parish } & Education & \multicolumn{1}{|c|}{$\begin{array}{c}\text { Age } \\
\text { Range }\end{array}$} & $\begin{array}{c}\text { Grades } \\
\text { Taught }\end{array}$ & Gender \\
\hline 1 & Bolivarian & La Vega & UCV & $20 \mathrm{~s}$ & $6^{\text {th }}$ & $\mathrm{M}$ \\
\hline 2 & Bolivarian & Petare & UCV & $40 \mathrm{~s}$ & $5^{\text {th }}$ and $6^{\text {th }}$ & $\mathrm{F}$ \\
\hline 3 & Bolivarian & El Recreo & UCV & $40 \mathrm{~s}$ & $5^{\text {th }}$ & $\mathrm{F}$ \\
\hline 4 & Bolivarian & Petare & UCV & $30 \mathrm{~s}$ & $4^{\text {th }}$ & $\mathrm{F}$ \\
\hline 5 & National & El Paraíso & UPEL & $50 \mathrm{~s}$ & $4^{\text {th }}$ & $\mathrm{F}$ \\
\hline 6 & National & Altagracia & UPEL & $30 \mathrm{~s}$ & $5^{\text {th }}$ & $\mathrm{F}$ \\
\hline 7 & National & La Vega & UBV & $30 \mathrm{~s}$ & $6^{\text {th }}$ & $\mathrm{F}$ \\
\hline 8 & National & La & & $50 \mathrm{~s}$ & $6^{\text {th }}$ & $\mathrm{M}$ \\
\hline 9 & National & La & & & & \\
\hline & & Candelaria & & $40 \mathrm{~s}$ & $4^{\text {th }}$ & $\mathrm{M}$ \\
\hline
\end{tabular}

${ }^{103}$ All of the teachers interviewed who reported where they received their pedagogical training reported having attended one of five institutions: most common were the Universidad Central de Venezuela (UCV) the country's flagship public university, the Universidad Pedagógica Experimental Libertator (UPEL) Venezuela's principal teachers' college, and the Universidad Bolivariana de Venezuela (UBV) - a relatively new university system established as part of the "Misión Sucre" in 2003. The latter institution, unlike its more established counterparts, is widely viewed as promoting an ideological perspective consistent with that of the Chávez (and now Maduro) government. One teacher each reported attending the Universidad Católica Andres Bello (UCAB) - a prestigious Catholic university with its central campus in Caracas - and the Universidad Metropolitana, a prestigious private university in northern Caracas. 


\begin{tabular}{|c|c|c|c|c|c|c|}
\hline 10 & National & El Paraíso & UPEL & $60 \mathrm{~s}$ & $6^{\text {th }}$ & $\mathrm{F}$ \\
\hline 11 & National & El Paraíso & UPEL & $40 \mathrm{~s}$ & $5^{\text {th }}$ & $\mathrm{F}$ \\
\hline 12 & National & $\begin{array}{l}\text { La } \\
\text { Candelaria }\end{array}$ & $\mathrm{UCV}$ & $30 \mathrm{~s}$ & $3^{\text {rd }}$ and $4^{\text {th }}$ & $\mathrm{F}$ \\
\hline 13 & National & Antímano & UBV & $20 \mathrm{~s}$ & $4^{\text {th }}$ & $\mathrm{F}$ \\
\hline 14 & National & Antímano & UBV & $30 \mathrm{~s}$ & $5^{\text {th }}$ & $\mathrm{F}$ \\
\hline 15 & Municipal & Chacao & UPEL & $30 \mathrm{~s}$ & $5^{\text {th }}$ & $\mathrm{F}$ \\
\hline 16 & Municipal & Chacao & UPEL & $30 \mathrm{~s}$ & $5^{\text {th }}$ & $\mathrm{F}$ \\
\hline 17 & Municipal & Chacao & UPEL & $60 \mathrm{~s}$ & $6^{\text {th }}$ & $\mathrm{F}$ \\
\hline 18 & Municipal & Petare & & $30 \mathrm{~s}$ & $4^{\text {th }}$ & $\mathrm{F}$ \\
\hline 19 & Municipal & Petare & & $30 \mathrm{~s}$ & $6^{\text {th }}$ & $\mathrm{F}$ \\
\hline 20 & Municipal & Petare & & $40 \mathrm{~s}$ & $6^{\text {th }}$ & $\mathrm{F}$ \\
\hline 21 & Municipal & Petare & & $30 \mathrm{~s}$ & $6^{\text {th }}$ & $\mathrm{F}$ \\
\hline 22 & Private & $\begin{array}{l}\mathrm{La} \\
\text { Candelaria }\end{array}$ & $\mathrm{UCV}$ & $40 \mathrm{~s}$ & $4^{\text {th }}$ & $\mathrm{F}$ \\
\hline 23 & Private & Chacao & $\mathrm{UCV}$ & $40 \mathrm{~s}$ & $4^{\text {th }}$ & $\mathrm{F}$ \\
\hline 24 & Private & Chacao & UCAB & $40 \mathrm{~s}$ & $5^{\text {th }}$ & $\mathrm{F}$ \\
\hline 25 & Private & Chacao & Metropolitana & $30 \mathrm{~s}$ & $5^{\text {th }}$ & $\mathrm{F}$ \\
\hline 26 & Private & El Recreo & $\mathrm{UCV}$ & $50 \mathrm{~s}$ & $6^{\text {th }}$ & $\mathrm{M}$ \\
\hline
\end{tabular}


Table 1. Textbook Representations of National Identity and History

\begin{tabular}{|c|c|c|c|}
\hline Issue & Pre-1999 Texts & $\begin{array}{c}\text { Non-Government } \\
\text { Texts }\end{array}$ & $\begin{array}{c}\text { Colección } \\
\text { Bicentenario }\end{array}$ \\
\hline Simón Bolívar & Liberal & Liberal & $\begin{array}{c}\text { Socialist/anti- } \\
\text { imperialist }\end{array}$ \\
\hline $\begin{array}{c}\text { Recent History } \\
\text { (1958-1999) }\end{array}$ & $\begin{array}{c}\text { Period of } \\
\text { democracy }\end{array}$ & $\begin{array}{c}\text { Period of } \\
\text { democracy }\end{array}$ & $\begin{array}{c}\text { Period of false } \\
\text { democracy }\end{array}$ \\
\hline $\begin{array}{c}\text { National Identity } \\
\text { Listorical Agency }\end{array}$ & Benevolent leaders & Benevolent leaders & Liberal-elitist \\
Subordinate sectors \\
\hline $\begin{array}{c}\text { Social } \\
\text { movemts/popular } \\
\text { resistance }\end{array}$ \\
\hline
\end{tabular}

